\title{
Genetic Correlation between Agronomically Important Traits in Yellow Passion Fruit
}

\author{
Leonarda Grillo Neves ${ }^{1}$, Claudio Horst Bruckner ${ }^{2}$, Marcelo Coutinho Picanço ${ }^{3}$, \\ Severino de Paiva Sobrinho ${ }^{4}$, Kelly Lana Araújo ${ }^{1}$, Petterson Baptista da Luz ${ }^{4}$, \\ Marco Antonio Aparecido Barelli ${ }^{4}$, Willian Krause ${ }^{4}$
} ${ }^{1}$ Laboratóriode Melhoramento Genético Vegetal, Universidade do Estado de Mato Grosso, Cáceres, Brasil; ${ }^{2}$ Departamento de
Fitotecnia, Universidade Federal de Viçosa, Viçosa, Brasil; ${ }^{3}$ Departamento de Entomologia, Universidade Federal de Viçosa, Viçosa,
Brasil; ${ }^{4}$ Departamento de Agronomia, Universidade do Estado de Mato Grosso, Cáceres, Brasil.

Email: leonardaneves@unemat.br

Received August $16^{\text {th }}, 2013$; revised September $16^{\text {th }}, 2013$; accepted October $15^{\text {th }}, 2013$

Copyright (C) 2013 Leonarda Grillo Neves et al. This is an open access article distributed under the Creative Commons Attribution License, which permits unrestricted use, distribution, and reproduction in any medium, provided the original work is properly cited.

\begin{abstract}
Breeding programs have sought to determine the minimum period of genotype evaluation, which is a long term-process. The objective of this work was to determine the association between qualitative traits of yellow passion fruit (Passiflora edulis Sims) and relate maturity to other characteristics. To carry out this work, 113 families of full-sibs and half-sibs were planted in Viçosa (MG), Brazil, in a randomized block experimental design arranged in sets (treatment groups). The association between the analyzed characteristics was studied using path analysis and canonical correlation techniques. It was found that lower-yielding but larger-fruit bearing genotypes of passion fruit plant also require more days until reaching anthesis. Round-shaped fruits are linked to higher contents of total soluble solids. More intense pulp color also indicates higher contents of total soluble solids. The riper the fruit, the more intensely orange is the color of the pulp. The ratio between the levels of total soluble solids and total titrimetric acidity was the main determinant of pulp color for passion fruit.
\end{abstract}

Keywords: Canonical Correlation; Passiflora edulis; Path Correlation

\section{Introduction}

Yellow passion fruit has drawn great interest from fruit producers, given its fast production cycle compared to other fruit species and high market demand for in natura consumption and industrialization, with whole juice emerging as the most economically important product within this trend [1]. Passion fruit has wide acceptance due to its taste, aroma and quality of its juice, and is consumed in several forms. The peel of the fruit, from which pectin is extracted, is used to produce jellies and pharmaceutical products $[2,3]$. Its seeds, which amount to nearly $10 \%$ of fruit weight, have fat contents of up to $25 \%$ [4], making them good sources of oils for the food and cosmetics industries $[5,6]$.

In Brazil, the main producing states during the 2011 harvest were: Bahia (410 thousand $t \cdot \mathrm{ha}^{-1} \cdot \mathrm{year}^{-1}$ ), Ceará (thousand $t \cdot \mathrm{ha}^{-1} \cdot$ year $^{-1}$ ), Espírito Santo (52 thousand $\left.\mathrm{t} \cdot \mathrm{ha} \mathrm{a}^{-1} \cdot \mathrm{year}^{-1}\right)$, Sergipe (45 thousand $\mathrm{t} \cdot \mathrm{ha}^{-1} \cdot \mathrm{year}^{-1}$ ) and Minas Gerais (38 thousand t $\cdot \mathrm{ha}^{-1} \cdot \mathrm{year}^{-1}$ ) [7].
In fruit species, fruit quality determines the acceptance of the product. Given the requirements set by producers and consumers, studying the correlations between gains in fruit traits is of great importance as it guides the future of breeding programs, by aiding in the improvement of several traits simultaneously. Several different biometric techniques are available to study the association between characteristics, such as canonical correlation and path analysis [8].

Canonical correlation analysis makes it possible to explain the relationship between two sets of variables, by finding a small number of linear combinations, in each variable set, so as to maximize possible correlations between the groups [8]. Analysis of canonical variables (obtained from linear combinations) can be quite useful in the study of multivariate dependencies. In plant genetic breeding, studying the direct and indirect effects of traits on a core variable makes it possible to evaluate whether the relationship between two variables has a 
cause and effect, or is determined by the influence of another variable or variables. Path analysis can be conducted through phenotypic, genotypic or environmental correlations [8].

The objectives of this work were to determine the association between qualitative traits of the passion fruit plant, and relate maturity to the other traits.

\section{Material and Methods}

A total of 113 families of full-and half-sibs were evaluated, descending from plants located in the area around the Bela Joana Company, in Campos dos Goytacazes-RJ, Brazil; these plants originated from São Francisco do Itabapoana, Maguary and Yellow Máster populations. The crosses that originated the progenies were carried out in Campos dos Goytacazes and followed the procedure described by Hallauer and Miranda Filho [9], based on Design I by Comstock and Robinson, in which a pollen donor plant (male parent) was crossed with five receptor plants (female parent). Thus, three female parent fruits were obtained to constitute the experiment.

To perform the study, all 113 families (full-sibs and half-sibs) were planted in an experimental area belonging to the Crop Science Department of the Federal University of Viçosa, located at the Mamão farm, municipality of Viçosa (MG), Brazil. Design I was used [9], in a randomized blocks experimental design arranged in sets (treatment groups), consisting of 03 sets: Set 01 comprised treatments 01 to 40 ; Set 02,41 to 80 ; and Set 03 contained treatments 81 to 113 . Within each set, the randomized blocks design was used, with three replications. Each experimental plot consisted of three plants, spaced 2.5 meters apart. The management system consisted of vertical cordons, at a spacing of 2.80 meters between rows. Drip irrigation was used and crop treatments consisted of those recommended for passion fruit plants.

Canonical correlation analysis evaluated the relationship between two groups of variables. The first (group $\mathrm{x}$ ) was characterized by the following traits:

1) Natural incidence of two-spotted spider mite: Mites were counted in the field, in the tertiary branch, on the $1^{\text {st }}$, $2^{\text {nd }}$ and $3^{\text {rd }}$ leaves. This count was carried out using an $8250 \mathrm{G}$ magnifier, $50 \mathrm{~mm}$ in diameter with $3.5 \times$ magnification, stipulating a $2.5 \mathrm{~cm}^{2}$ field of vision. The count was undertaken on the trilobate leaf of the passion fruit plant, on the abaxial surface, and on the two central intersection points with the midrib. The number of mites was estimated by adding both quadrants of each leaf, for all three leaves, and from the average obtained from all three plants per plot.

2) Days until anthesis (DUA): DUA was determined by counting the number of days since field sowing until the first flower appeared on the plot.

3) Total soluble solids content ( $\left({ }^{\circ} \mathrm{Brix}\right)$ (TSS): After the plants began to bear fruits, treatments were evaluated through the averages of the plots. TSS was determined through refractometry, using a portable refractometer, with readings in the $0-32{ }^{\circ}$ Brix range, following extraction and filtration of the juice from each fruit through nylon screen sieve.

The second group (group y) was characterized by the following traits:

1) Yield of the first flowering (g/plot $\left.\left(21 \mathrm{~m}^{2}\right)\right)(\mathrm{YFF})$ : YFF was defined from average fruit weight and by the number of fruits harvested in the first flowering.

2) Pulp weight with seeds (PW): calculated on a digital scale and expressed in grams.

3) Equatorial diameter (ED) and fruit length $(\mathrm{mm})(\mathrm{FL})$ : measured by a pachymeter and expressed in millimeters.

Path analysis was carried out between the following traits:

1) Fruit maturity (Main Variable) (FM). The classification of fruits with regard to maturity was conducted by separating fruits according to peel color, according to a grading scale [10], as described in Table 1.

2) Total titrimetric acidity (TTA). Total titrimetric acidity was determined in accordance with the methodology recommended by the AOAC [11] and modified by Araújo [12], by titrating $5 \mathrm{ml}$ of juice from each fruit with $\mathrm{NaOH} 0.5 \mathrm{~mol} \cdot \mathrm{L}^{-1}$, under agitation, for each of the three types of maturity established previously. Next, these were diluted in distilled water at a ratio of $5: 1$, using phenolphthalein at $1 \mathrm{~g} / \mathrm{L}$ as indicator. The results were expressed in gram equivalent of citric acid per 100 $\mathrm{ml}$ of juice.

3) TSS/TTA. The ratio was obtained by dividing the content of total soluble solids (TSS) by total titrimetric acidity (TTA).

4) Pulp color (PC). Pulp color was determined using the color scale defined in the Table 2.

After the juice was extracted from each fruit, from each of the three maturity points, scores were attributed by visual comparison established between the scoring chart and $20 \mathrm{ml}$ of pure seedless juice. The visual comparison was performed by five evaluators, and the final result was obtained by identifying the largest number of indications into one of the classes.

\subsection{Canonical Correlation Analysis}

Two groups of $\mathrm{X}$ and $\mathrm{Y}$ variables were admitted, defined

Table 1. Grading scale used to evaluate the maturity of passion fruit.

\begin{tabular}{cc}
\hline Score & Description \\
\hline 1 & Predominantly green, at least $30 \%$ of final color. \\
2 & Predominantly in final color. Combined with green. \\
3 & Fully infinal color. Yellow. \\
\hline
\end{tabular}


Table 2. Grading scale used to evaluate the color of passion fruit.

\begin{tabular}{|c|c|c|c|c|c|c|}
\hline Score & 6 & 5 & 4 & 3 & 2 & 1 \\
\hline \multicolumn{7}{|l|}{ Colors } \\
\hline Description & Orange & Light orange & Golden & Yellow & Light yellow & Whitish yellow \\
\hline Hue & 17 & 25 & 34 & 42 & 42 & 42 \\
\hline Saturation & 255 & 255 & 255 & 255 & 255 & 255 \\
\hline Brightness & 128 & 128 & 128 & 128 & 204 & 242 \\
\hline Red & 255 & 255 & 255 & 255 & 255 & 255 \\
\hline Green & 102 & 153 & 204 & 255 & 255 & 255 \\
\hline Blue & 0 & 0 & 0 & 0 & 153 & 249 \\
\hline
\end{tabular}

as:

$X^{\prime}=\left[x_{1}, x_{2}, \cdots, x_{p}\right]=$ vector of the measurements of $p$ traits that comprise group I.

$Y^{\prime}=\left[y_{1}, y_{2}, \cdots, y_{q}\right]=$ vector of the measurements of $q$ traits that comprise group II.

The estimation of the maximum correlation between linear combinations of traits from groups I and II, and the respective weight ages of the traits in each linear combination, was given by:

$X_{1}=a_{1} x_{1}+a_{2} x_{2}+\ldots+a_{p} x_{p}$, e, $Y_{1}=b_{1} y_{1}+b_{2} y_{2}+\ldots+$ $b_{q} y_{q}$. In which,

$a^{\prime}=\left[a_{1}, a_{2}, \cdots, a_{p}\right]=1 \times p \quad$ vector of weights of the traits of group I.

$b^{\prime}=\left[b_{1}, b_{2}, \cdots, b_{q}\right]=1 \times q$ vector of weights of the traits of group II.

The first canonical correlation was expressed by:

$r_{1}=\operatorname{Cov}\left(X_{1}, Y_{1}\right) /\left(V\left(X_{1}\right) \cdot V\left(Y_{1}\right)\right)^{0.5}$, so that:

$\operatorname{Cov}\left(X_{1}, Y_{1}\right)=a^{\prime} S_{12} b, V\left(X_{1}\right)=a^{\prime} S_{11} a, V\left(\mathrm{y}_{1}\right)=a^{\prime} S_{22} b$, in which:

$S_{11}=p \times p$ matrix of covariances between the traits of group I;

$S_{22}=q \times q$ matrix of covariances between the traits of group II;

$S_{12}=p \times q$ matrix of covariances between the traits of groups I and II.

\subsection{Path Analysis}

Path analysis consisted of studying the direct and indirect effects of the abovementioned explanatory variables (X) on the dependent variable passion fruit pulp color (Y). Because $\mathrm{Y}$ is regarded as a complex characteristic, resulting from combined action by other traits, it is possible to establish the following model:

$Y=\beta_{1 \times 1}+\beta_{2 \times 2}+\ldots+\beta_{n \times n}+\varepsilon$, in which: $X_{1}, X_{2}, \ldots, X_{n}$ are the explanatory variables, and $\mathrm{Y}$ is the core variable (or dependent variable). The direct and indirect effects of the explanatory variables were on the core variable were estimated. Thus: $r_{i y}=p_{i}+\sum_{j \neq 1}^{n} p_{i j} r_{i j}$, in that:

$r_{i y}$ : correlation between the main variable $(y)$ and the $i^{\text {th }}$ explanatory variable;

$p_{i}$ : measurement of the direct effect of variable $i$ on the main variable; and

$p_{j} r_{i j}$ : measurement of the indirect effect of variable $i$, via variable $j$, on the main variable.

\subsection{Statistical Analyses}

The methodology described by [13] and Genes software application [14] version 2009, were used for all biometric analyses.

\section{Results and Discussion}

\subsection{Canonical Correlations}

An absence of collinearity was observed between the analyzed characteristics by diagnosing multicollinearity, as per [8]. Thus, it became possible to perform canonical analyses. The presence of collinearity, resulting from correlations between the analyzed characteristics, makes results less precise in canonical correlation analyses [15].

Analyzing the data in Table 3, it was possible to observe that all three canonical correlations were significant by Chi-square test at $1 \%$ probability. This demonstrates that all three trait groups are related to one another in a dependent manner [13]. With regard to the first canonical pair, it was demonstrated that genotypes of the passion fruit plant that needed more days until anthesis yielded less in the first flowering, produced larger fruits (length and equatorial diameter) with lighter pulp weight. Therefore, in this population under study, lower-yielding genotypes were late in production as well.

With regard to the second canonical pair, it was detected that fruits with higher content of total soluble solids tend to have a more rounded shape, showing greater equatorial diameter and shorter length (Table 3). In order to find out the canonical correlations between yellow passion fruit characteristics, Viana et al. [16] observed that, in general, individuals with larger fruits had higher TSS levels, corroborating the results of our study.

Akamine and Girolami [17] and Albuquerque et al. [18] 
Table 3. Canonical correlationsandcanonical pairs estimated between primary (Group I) and secondary (Group II) components with regard to the characteristics ofyellow passion fruit. Viçosa, 2006.

\begin{tabular}{ccccc}
\hline \multirow{2}{*}{ Groups } & Characteristics & \multicolumn{2}{c}{ Canonical Pairs } \\
\cline { 3 - 5 } & & NA & $1^{\text {st }}$ & $2^{\text {nd }}$ \\
\hline \multirow{2}{*}{ I } & DAF & -0.0908 & -0.5275 & 0.8637 \\
& TSS & 0.9481 & 0.1052 & 0.3330 \\
& YFF & -0.2405 & 0.8933 & 0.3946 \\
II & PW & -0.7566 & -0.4476 & -0.1777 \\
& FL & -0.0603 & -0.4411 & 1.2147 \\
ED & ED & 0.5557 & -0.9377 & -0.9195 \\
& & 0.5533 & 0.9044 & 0.1321 \\
\hline
\end{tabular}

${ }^{* *}$ Significant by Chi-square test at $1 \%$ probability. Group I: (NA) number of mites, (DUA) days until anthesis, and (TSS) content of total soluble solids ( ${ }^{\circ}$ Brix). Group II: (YFF) yield of first flowering (g/plot $\left.\left(21 \mathrm{~m}^{2}\right)\right)$, (PW) pulp weight (g), (ED) equatorial diameter and (FL) fruit length (mm).

detected correlations between juice percentage and pulp weight, respectively, with both diameter and fruit length. Ferreira et al. [19] and Oliveira [20] also observed a stronger correlation between fruit equatorial diameter and fruit weight that that between fruit length and weight in yellow passion fruit plant. Negreiros et al. [21] concluded that these correlations are important, as they indicate that plants with heavier fruits can be selected by measuring the equatorial diameter of fruits, still in the field, eliminating the need to weigh them, which could significantly facilitate selection procedures.

Still according to Negreiros et al. [21], selection of oval-shaped fruits, although justifiable due to market demand, should not be applied with the objective of increasing pulp yield, given that the effect of the equatorial diameter is greater than that of length in pulp yield and in the mass of the fruit and pulp alike.

Attempting to evaluate the degree of association between economically important characteristics of yellow passion fruit population, Gonçalves et al. [22] detected through estimation of the phenotypic and additive genetic coefficients that the trait number of fruits per plant was negatively associated with fruit weight, length and width, and positively associated with peel thickness. Moreover, fruit weight showed phenotypic and additive genetic correlations with all other characteristics, except number of fruits per plant. Thus, according to those authors, an increase in fruit size can result in lower production in the numbers of fruits, so that more elaborate breeding methods may be required in order to obtain a high-yielding population and fruits with more commercially acceptable sizes.

Analyzing the third canonical pair, it was observed that a higher natural incidence of spider mites resulted in reduced productivity of the first flowering and smaller fruit length. However, there was a positive association between mite incidence and pulp weight and equatorial width of fruits (Table 3). There are currently no chemical products registered for passion fruit crops by Brazil's Ministry of Agriculture, Livestock and Food Supply (MAPA) to control mites. Some references found in the literature regarding the use of acaricides in passion fruit plants are based on experimental results. For this study, it can be argued that the reduced fruit length dos fruits and greater pulp weight led to a higher number of mites. More in-depth studies are suggested in order to determine whether fruits with higher juice yield are also more susceptible to mites. Currently, chemical control is most common, but is also more problematic as mites are highly capable of developing resistance against several groups of acaricides, according to reports by Maruyama et al. [23]. Within this context, the gain obtained by selecting families of passion fruit plant that combine productivity and lower economic losses from mite attacks can be most valuable.

\subsection{Path Analysis}

The estimations of the direct and indirect effects of the primary qualitative components on passion fruit maturity are represented in Table 4. It is seen that total soluble solids content, TSS, showed a direct positive effect with regard to the core variable (pulp color), making it clear that more intense pulp color is also characterized by higher TSS contents.

Correlation coefficients are unfolded by path analysis, developed by Wright $[24,25]$ and in greater detail by $\mathrm{Li}$ [26]. Although a correlation is intrinsic to two traits in a given experimental condition, in studies its decomposition is dependent on the set of traits. In cases where a single causal model is considered, path analysis is merely the standardized partial regression analysis, useful in unfolding correlation coefficients into direct and indirect effects [13].

Ina study on the association between productive traits 
of the passion fruit plant, Albuquerque [27] detected that it can be concluded from the evaluation of simple and partial correlations simples and from path analysis that it is possible to achieve gains in fruit weight through indirect selection on fruit length and diameter and on pulp weight. This confirms the usefulness of studies on the correlations between characteristics of yellow passion fruit.

Viana et al. [16] studied the simple and canonical correlations between yellow passion fruit characteristics, evaluating five morphological traits related to fruit production (number of fruits per plant, fruit weight, fruit length, fruit width and peel thickness) and three fruitquality traits (degrees Brix, acidity and percentage of juice), detecting the existence of significant positive genetic correlations, in both environments, between fruit weight and width, fruit width and length, fruit acidity and width, and a negative correlation between degree Brix and fruit length.

Pulp color score has a direct positive effect on fruit maturity, showing that the riper the fruit, the more intensely orange was pulp color. The variable base (pulp color) showed a high negative correlation with pulp acid-

Table 4. Direct and indirect effects of primary qualitative components with regard to passion fruit pulp color.

\begin{tabular}{|c|c|c|}
\hline Characteristic & Effect & Estimation \\
\hline \multirow{5}{*}{ TSS } & Direct on Pulp color & 0.8184 \\
\hline & Indirect via FM & -0.0744 \\
\hline & Indirect via TTA & -0.5115 \\
\hline & Indirect via TSS/TTA & 0.7657 \\
\hline & Total & 0.9982 \\
\hline \multirow{5}{*}{ FM } & Direct on Pulp color & 0.7683 \\
\hline & Indirect via TSS & -0.0747 \\
\hline & Indirect via TTA & -0.5092 \\
\hline & Indirect via TSS/TTA & 0.8090 \\
\hline & Total & 0.9933 \\
\hline \multirow{5}{*}{ TTA } & Direct on Pulp color & -0.5084 \\
\hline & Indirect via TSS & 0.7703 \\
\hline & Indirect via FM & -0.8071 \\
\hline & Indirect via TSS/TTA & -0.0745 \\
\hline & Total & 0.9943 \\
\hline \multirow{5}{*}{ TSS/TTA } & Direct on Pulp color & 0.8224 \\
\hline & Indirect via TSS & 0.7559 \\
\hline & Indirect via FM & -0.0735 \\
\hline & Indirect via TTA & -0.5090 \\
\hline & Total & 0.9958 \\
\hline
\end{tabular}

(FM) fruit maturity, (TTA) total titrimetric acidity, (TSS) total soluble solids $\left({ }^{\circ}\right.$ Brix) and (TSS/TTA) ratio between TSS and TTA. ity, and a positive correlation with the ratio between the content of total soluble solids and total titrimetric acidity (TSS/TTA), demonstrating that fruits with more intense pulp were also more acidic and had a higher TSS/TTA ratio.

The ratio between the content of total soluble solids and total titrimetric acidity was the main determinant of pulp color of passion fruit, in the present study. Thus, it is possible to achieve gains in the ratio between the content of total soluble solids and total titrimetric acidity (TSS/TTA) through direct selection for pulp color. According to Vangdal [28], the TSS/TTA ratio must be considered as an indicator of fruit palatability, meaning that a high ratio between these traits is highly important, especially for the juice industry.

\section{Conclusions}

Lower-yielding and smaller passion fruit plant genotypes are characterized by requiring more days until anthesis.

More rounded fruits show higher content of total soluble solids.

The ratio between the content of total soluble solids and total titrimetric acidity was the main determinant of passion fruit pulp color.

\section{REFERENCES}

[1] M. L. Zeraik, C. A. M. Pereira, V. G. Zuin and J. H. Yariwake, "Passion Fruit: A Functional Food?" Revista Brasileira de Farmacognosia, Vol. 20, No. 3, 2010, pp. 459-471. http://dx.doi.org/10.1590/S0102-695X2010000300026

[2] E. D. Oliveira, M. R. F. Nascimento, S. V. Borges, P. C. N. Ribeiro and V. R. Ruback, "Aproveitamento Alternativo da Casca do Maracujá-Amarelo (Passiflora edulis f. flavicarpa) Para Produçã̃o Dedoce em Calda," Ciência e Tecnologia de Alimentos, Vol. 22, No. 3, 2002, pp. 259262. http://dx.doi.org/10.1590/S0101-20612002000300011

[3] J. S. Medeiros, M. F. F. M Diniz, A. U. O. S. Srur, M. B. Pessoa, M. A. A. Cardoso and D. F. Carvalho, "Ensaios toxicológicos Clínicos da Casca do Maracujá-Marelo (Passiflora edulis, f. flavicarpa), Como Alimento com Propriedadedesaúde," Revista Brasileirade Farmacognosia, Vol. 19, No. 2A, 2009, pp. 394-399. http://dx.doi.org/10.1590/S0102-695X2009000300010

[4] F. C. A. V. Matsura and M. I. S. Folegatti, "Produtos," In: A. de A. Lima, Ed., O Cultivodo Maracujá, Circular Técnico, No. 35, Embrapa Mandioca e Fruticultura, Cruz das Almas, 1999, pp. 103-108.

[5] R. A. Ferrari, C. G. Heck and I. N. M. Silva, "Deter-Minaçã̃o da Estabilidadeoxidativado Óleodesementedemaracujá Amarelo (Passiflora edulis)," Unopar Científica Ciências Biológicas e da Saúde, Vol. 8, No. 1, 2006, pp. 83-85.

[6] C. K. Togashi, J. B. Fonseca, R. T. R. N. Soares, A. 
Gaspar and E. Detmann, "Composition of Fatty Acids in Tissues of Broilers Fed By-Products of Passion Fruit," Revista Brasileira de Zootecnia, Vol. 36, No. 6, 2007, pp. 2063-2068.

http://dx.doi.org/10.1590/S1516-35982007000900016

[7] IBGE, "Instituto Brasileiro de Geografia e Estatística," 2013.

http://www.ibge.gov.br/home/estatistica/economia/pam/2 011/default_pdf.shtm

[8] C. D. Cruz and P. C. S. Carneiro, "Modelos Biométricosaplicadosaomelhoramentogenético," Viçosa, 2003.

[9] A. R. Hallauer and J. B. Miranda Filho, "Quantitative Genetics in Maize Breeding," 2nd Edition, Iowa State University Press, Ames, 1988.

[10] "Programa Brasileiro Para a Melhoria dos Padrõescomerciais e Embalagensde Hortigranjeiros," MaracujáAzedo, Ceasa, Campinas, São Paulo, 2000. http://www.ceasacampinas.com.br/novo/Serv_padro_mar acuja.asp

[11] AOAC, "Official Methods of Analyses," Association of Official Analytical Chemists, Washington DC, 1990.

[12] R. da C. Araújo, "Produção, Qualidade de Frutos e Teores Foliares de Nutrientes no Fruto de Maracujá Amarelo em Resposta à Nutrição Potássica," Tese (Doutorado em Fitotecnia), Universidade Federal de Viçosa, Viçosa, 2001.

[13] C. D. Cruz, A. J. Regazzi and P. C. S. Carneiro, "Modelos Biométricosaplicadosaomelhoramentogenético II," 3rd Edition, UFV, Viçosa, 2004.

[14] C. D. Cruz, "Programa Genes: Biometria. Versão Windows; Aplicativocomputacional em Genética e Estatística," UFV, Viçosa, 2006.

[15] S. P. Carvalho, "Métodos Alternativos de Estimação de Coeficientes de Trilha e Índices de Seleção, Sob Multicolinearidade," UFV, Viçosa, 1995.

[16] A. P. Viana, T. N. S. Pereira, M. G. Pereira, M. M. Souza, J. F. M. Maldonado and A. T. do Amaral Júnior, "Simple and Canonic Correlation between Agronomical and Fruit Quality Traits in Yellow Passion Fruit (Passiflora edulis f. flavicarpa) Populations," Crop Breeding and Applied Biotechnology, Vol. 3, No. 2, 2003, pp. 133-140.

[17] E. K. Akamine and G. Girolami, "Pollination and Fruit Set in the Yellow Passion Fruit," University of Hawaii, Honolulu, 1959.

[18] A. S. Albuquerque, C. H. Bruckner, C. D. Cruz, V. W. D. Casali, R. da C. Araújo, A. E. Moreira and J. A. de Souza,
"Possibilidade de Seleção Indireta Para Peso do Fruto e Rendimento em Polpa em Maracujá (Passiflora edulis Sims)," In: Congresso Brasileiro de Fruticultura, 17, Embrapa, Belém, 2002.

[19] F. R. Ferreira, P. C. Vallini, C. Ruggiero and A. LamSanchez, "Correlações Fenotípicas Entre Diversas Características do Fruto do Maracujá Amarelo (Passiflora edulis flavicarpa)," In: Congresso Brasileiro de Fruticultura, 3, Universidade Federal Rural do Rio de Janeiro, Rio de Janeiro, 1975, pp. 481-489.

[20] J. C. Oliveira, "Melhoramento Genético de Pasiflora edulis f. flavicarpa Deg. Visando ao Aumento de Produtividade," Tese (Livre-Docência)—Faculdade de Ciências Agrárias e Veterinárias, Universidade Estadual Paulista, Jaboticabal, 1980.

[21] J. R. da S. Negreiros, V. de S. Alvares, C. H. Bruckner, M. A. D. Morgado, and C. D. Cruz, "Relação Entre Características Físicas e o Rendimento de Polpa de Maracujá-Amarelo," Revista Brasileira de Fruticultura, Vol. 29, No. 3, 2007, pp. 546-549. http://dx.doi.org/10.1590/S0100-29452007000300026

[22] G. M. Gonçalves, A. P. V. Viana, L. S. Reis, F. V. Bezerra Neto, A. T. do Amaral Júnior and L. S. Reis, "Correlações Fenotípicas e Genético-Aditivas em Maracujá Amarelo Pelo Delineamento I," Ciência Agrotecnologia, Vol. 32, No. 5, 2008, pp. 1413-1418.

[23] W. I. Maruyama, L. C. Toscano, A. L. Boiça Júnior and J. C. Barbosa, "Resistência de Genótipos de Tomateiro ao Ácaro Rajado," Horticultura Brasileira, Vol. 20, No. 3, 2002, pp. 480-484. http://dx.doi.org/10.1590/S0102-05362002000300017

[24] S. Wright, "Correlation and Causation," Journal of Agricultural Research, Vol. 20, 1921, pp. 557-585.

[25] S. Wright, "The Theory of Path Coefficients-A Replay to Niles' Criticism," Genetics, Vol. 52, 1923, pp. 127138.

[26] C. C. Li, "Grouping Genotypes by a Cluster Method Directly Related to Genotype-Environment Interaction Mean Square," Theoretical and Applied Genetics, Vol. 62, No. 3, 1982, pp. 277-280.

[27] A. S. Albuquerque, "Seleção de Genitores e Híbridos em Maracujazeiro (Passiflora edulis Sims)," Tese (Doutorado em Fitotecnia), Universidade Federal de Viçosa, Viçosa, 2001.

[28] E. Vangdal, "Postharvest Ripening of Plums," Forsking og Forsøk i Landbruket, Vol. 32, No. 1, 1981, pp. 13-20. 